\title{
The Cognitive Difference of Performance Evaluation: Focus on County-level Government
}

\author{
Jia-Zheng MA* \\ Department of Public Administration, Shanghai Administration Institute, Shanghai, 200233, China \\ *Email: wwwmjz@163.com
}

Keywords: County-level government, Performance evaluation, Cognition difference.

\begin{abstract}
Considering the deep influences of individual cognitive differences on their opinions, attitudes and behaviors, we probe deeply into the three involved parties' awareness of the government performance evaluation and analyze their cognitive situation and reasons to the issue, as well as the reflected problems based on the interview; besides, it also has proposed the countermeasures and solutions to the problems on the basis of the achieved results in local government performance evaluation, expecting to provide references for the performance evaluation of county-level governments in subject selection, improvement of public participation and construction of external environment.
\end{abstract}

\section{Introduction}

When applying the evaluation theories into practice, all participators undertaking the practical works will stand out. Currently, the views that the participators (generally divided into internal and external ones) will affect the validity of government performance evaluation have been accepted [1] With the increasing practice of performance evaluation at county-level governments, relevant participators have formed a stable cognition of the connotation and function of the government performance evaluation. Moreover, owing to the difference in social, economic and cultural development between counties and provinces and cities, the cognition of different participators is also different. As the individual's behaviors is directly related to their cognition, it is important for us to carefully analyze the cognition of all participators to the evaluation to guide our behavior in the evaluation activity [2]. The problems in their cognition can directly reflect the difference of government performance evaluation between the actual state and the state-should-be, which is beneficial for us to solve the effective connection between the theoretical research and evaluation practice.

Nevertheless, it still lacks of reliable empirical data on how the different cognition of different participators influence the actual state and expected state of performance evaluation, since most research just list the influences of subjective cognition on the performance evaluation like distortion of evaluation process and evaluation data as well as the misunderstanding of performance information, which are basically the subjective judgment rather than the conclusion from specific data. To make up the insufficiency in the exploration, this paper attempts to carry out field research in county-level government of different places and the find out how the subjective cognition affect the actual state and expected state of performance evaluation based on the investigated data.

\section{Research Design}

We firstly started from the theoretical achievements to sort out the transform process from theoretical research into practice, and then laid great emphasis on the influences of subjective cognition on the actual practice during the transform process, by which it worked out the approaches and methods to realize the effective connection between actual state and expected state of performance evaluation. For the purpose of deep analysis, the participators in performance evaluation of county-level governments are divided into external and internal ones according to whether they attend the daily administrative work of the government, among which the county-level 
government leaders (county magistrate or executive vice county mayor) and directors of all government sectors are representatives of internal participators while the service objects the external ones. The reason of selecting county government leaders and heads is to inspect the cognition degree of internal participators on the government performance evaluation, as well as whether the senior level civil servants hold the same views with those working on the frontline on the same issue and whether it meets the theoretical expectation. The reason why selecting service objects for interview is to learn the cognition state of external participators in government performance evaluation, to explore whether their cognition is different with that of internal participators and with the theoretical expectation.

By the sampling survey in the 22 counties in the western regions in China including Sichuan Province, Gansu Province and Shaanxi Province, etc, we took the structured interview to investigate the cognition of the three types of participators including county-level government leaders (county magistrate or executive vice county mayor), directors of government sectors and service objects on the government performance evaluation (Table 1).

Table1. Interviewee information

\begin{tabular}{l|l|l|l}
\hline Variable & Categories & Number & Percentage \\
\hline \multirow{3}{*}{ Gender } & Male & 88 & 68.2 \\
\cline { 2 - 4 } & Female & 41 & 31.8 \\
\hline \multirow{4}{*}{ Age } & Under 30 & 21 & 16.3 \\
\cline { 2 - 4 } & $31-40$ years & 37 & 28.7 \\
\cline { 2 - 4 } & $41-49$ years & 45 & 34.9 \\
\cline { 2 - 4 } & Over 50 & 26 & 20.1 \\
\hline \multirow{2}{*}{ Educational background } & Below college & 32 & 24.8 \\
\cline { 2 - 4 } & Bachelor degree and above & 97 & 75.2 \\
\hline \multirow{3}{*}{ Status } & Government Leaders & 16 & 12.4 \\
\cline { 2 - 4 } & Sector Directors & 39 & 30.2 \\
\cline { 2 - 4 } & Service Objects & 74 & 57.4 \\
\hline
\end{tabular}

\section{Results and Discussion}

Three core issues are contained in the structured interview, i.e., "whose evaluation on the government performance is the most effective among the three types of participators?", "which item is the most important among the evaluation contents?" and "what is the most crucial problem in the current government performance evaluation?"; all the three questions are the hot topics in the current research and practice of government performance evaluation based on the existing research achievements. Views of different scholars on each question we form the five options for the interviewees to select. We further divided the interview results based on the concentration of options to analyze the problems reflected in generalization and differentiation cognition as well as their solutions.

\section{Generalization Cognition}

From the interview it can be seen that all participators show the same views on the last question (Table 2). Almost $70 \%$ respondents believe that low public participation is the key problem in the practice of government performance evaluation, which indicates that both internal and external participators think the public participation is still limited in the county-level government performance evaluation. The finding is basically conforming to the results obtained after reviewing the literature that most research achievements of local government performance evaluation with public participating are seen in the province- and city-level governments. As a result, although we have made great progress in the public participation (for example, thousands of people evaluating the government at Zhuhai City, thousands of people testing the political and industrial ethos at Daqing City, Kaifeng City, Yantai City and Changchun City; third-party evaluating the government in Gansu Province) [3]. But at the county level, people are still limited to participate. To change the situation, we shall first transfer the government functions to realize the scientific position of government's role and thus determine the basic theory of co-governance. The government shall get 
rid of the conventional bureaucrat oriented consciousness and form the philosophy of responsible government with the principle of serving the people, so as to build a harmonious atmosphere for the public to participate in the government performance evaluation. Secondly, it shall enhance the interaction with the basic-level mass to cultivate the civic awareness and encourage the public to take part in the government performance evaluation [4]; at the same time, it shall improve the quality of the citizens based on relevant educational resources to guarantee the orderly participation. Thirdly, it shall regulate the public participation from the aspect of system design to determine the participating contents, methods and approaches, so as to broaden the channel of public participation by improving the system construction.

Table2. Opinion summarizing

\begin{tabular}{|c|c|c|c|c|c|}
\hline \multirow[b]{2}{*}{ Opinion Options } & \multicolumn{3}{|c|}{ Opinion Count } & \multirow[b]{2}{*}{ Total } & \multirow[b]{2}{*}{ Percentage } \\
\hline & $\begin{array}{l}\text { Government } \\
\text { Leaders }\end{array}$ & $\begin{array}{l}\text { Sector } \\
\text { Directors }\end{array}$ & $\begin{array}{l}\text { Service } \\
\text { Objects }\end{array}$ & & \\
\hline A. Evaluation is unvalued by government. & 0 & 1 & 6 & 7 & 5.4 \\
\hline B. Evaluation process is not scientific. & 1 & 4 & 3 & 8 & 6.2 \\
\hline C. Evaluation results are not accurate. & 4 & 9 & 4 & 17 & 13.2 \\
\hline D. Public participation is not enough. & 8 & 21 & 59 & 88 & 68.2 \\
\hline E. Necessary rules and regulations are lack. & 3 & 4 & 2 & 9 & 7.0 \\
\hline
\end{tabular}

\section{Differentiation Cognition}

According to the analysis of the interview results, the different classification of subjects have brought the obvious conformity effect in some questions, namely, respondents of the same type hold the same opinions on the question but take a complete different attitude with respondents of other types.

\section{Cognition of "Whose Evaluation on the Government Performance is the most Effective?"}

In terms of the question, respondents like county magistrate hold the opinion that it shall be the service objects, supervisors, sectors at the same level and relevant experts to evaluate the government performance, and their priority lowered accordingly. Respondents like directors of the sectors believe the government performance shall be evaluated by the service objects, supervisors and relevant experts with their priority decreased orderly; but the service objects suggest that they are the one who can judge the government performance. It can be seen that all parties agree that government performance shall be evaluated by the service objects, but only the internal respondents like county magistrate and sector heads think it shall be evaluated by the supervisors and relevant experts (Table 3).

Table3. Opinion summarizing

\begin{tabular}{|c|c|c|c|c|c|}
\hline \multirow[b]{2}{*}{ Opinion Options } & \multicolumn{3}{|c|}{ Opinion Count } & \multirow[b]{2}{*}{ Total } & \multirow[b]{2}{*}{ Percentage } \\
\hline & $\begin{array}{l}\text { Government } \\
\text { Leaders }\end{array}$ & $\begin{array}{l}\text { Sector } \\
\text { Directors }\end{array}$ & $\begin{array}{l}\text { Service } \\
\text { Objects }\end{array}$ & & \\
\hline A. Superior department & 4 & 13 & 3 & 20 & 15.5 \\
\hline B. Sectors at the same level & 3 & 0 & 1 & 4 & 3.1 \\
\hline C. Relevant experts and scholars & 2 & 10 & 11 & 23 & 17.8 \\
\hline D. Service objects & 6 & 13 & 53 & 72 & 55.8 \\
\hline E. The third-party evaluation agencies & 1 & 3 & 6 & 10 & 7.8 \\
\hline
\end{tabular}

From what we have discussed above, different participators all recognize the role of the public in government performance evaluation, but difference still exist in the objectives because of their interest ascription. The external parties aim to attend the evaluation and learn the assessment information, so that the act of government can be improved in the favor of them; consequently, they are inclined to trust their own perception rather than accept the judgment from the internal parties or relevant experts while judging the government performance [5]. As a matter of fact, from the perspective of 360-degree assessment, the judgments from the supervisors, sectors at the same level, service objects and even themselves are beneficial to the comprehensive and objective evaluation on government performance, so we can't say whose evaluation is the most effective mechanically 
but shall distribute the proportion to their opinions based on the category of government performance evaluation. For the evaluation by the first-party and second-party, the views of the supervisors and participators at the same level will serve as primary reference and that of the service objects and themselves as supplemental material [6]. However, in terms of evaluation by the third-party, we should first consider the service objects' views and weaken the proportion of opinions of the other three parties. The organizers shall adopt and discard the views of different parties according to the actual situation while conducting the performance evaluation of county-level governments.

\section{Cognition of "Which Item is the most Important Among the Evaluation Contents?"}

When it comes to the specific job, respondents like county magistrate and directors of government sectors focus most on the law-based administration of the government but the service objects care more about the incorrupt governance. Outside of work, about $60 \%$ respondents agree that the public satisfaction is the most important index in government performance evaluation, indicating that all three kinds of respondents regard the public satisfaction as the crucial factor (Table 4).

Table4. Opinion summarizing

\begin{tabular}{|c|c|c|c|c|c|}
\hline \multirow[b]{2}{*}{ Opinion Options } & \multicolumn{3}{|c|}{ Opinion Count } & \multirow[b]{2}{*}{ Total } & \multirow[b]{2}{*}{ Percentage } \\
\hline & $\begin{array}{l}\text { Government } \\
\text { Leaders }\end{array}$ & $\begin{array}{l}\text { Sector } \\
\text { Directors }\end{array}$ & $\begin{array}{l}\text { Service } \\
\text { Objects }\end{array}$ & & \\
\hline A. Administration according to law & 7 & 12 & 5 & 24 & 18.6 \\
\hline B. Keeping honest and upright & 1 & 5 & 13 & 19 & 14.8 \\
\hline C. Economic development level & 2 & 2 & 3 & 7 & 5.4 \\
\hline D. Public satisfaction & 5 & 18 & 53 & 76 & 58.9 \\
\hline E. Civil servant satisfaction & 1 & 2 & 0 & 3 & 2.3 \\
\hline
\end{tabular}

The results show that different evaluation parties focus on different aspects of the government's work. As the internal party, the county and sector heads lay great emphasis on the law-based administration, reflecting the basic requirements and principles of the government in self-construction. However, the public, as the external party, cares more about the construction of incorrupt government, showing the public's desire for supervising the daily work of government's internal personnel and the social equity. The State Council published the Outline for Promoting Law-based Administration in an All-round Way in 2004, which set the objective of establishing a law-based government and specified the guidelines, specific objective, basic principles and requirements, major tasks and measures for promoting the law-based administration. It can be seen that the basic system insurance for law-based administration has been completed, and the internal parties' concern on the issue reflect that their political awareness has raised and become an organizational routine. On the contrary, the public's concern on the incorrupt government also reflects that the government leaders have already made great progress, but there is still quite a distance to the public's requirements [7]. In 2011, the Central Commission for Discipline Inspection issued the Guidelines for CPC Cadres to Ensure the Clean Practice in Their Work (known as Code of Ethics), which put forward the specific requirements for the construction of incorrupt governance. Only when the internal parties strictly implement the two items mentioned above can they satisfy the public's desire for social equity and promote the healthy development of a harmonious society.

What's more, the interview findings also indicate that the public satisfaction is the chief carrier for the public to judge the government performance, verifying the old saying that golden cups and silver cups are nothing valuable compared with the public praise. This is corresponding to the basic functions of county-level governments, because they are the direct suppliers of public products and services, the public will directly sense the quality of product and service and express it through their satisfaction degree. Therefore, using the satisfaction to evaluate the government performance has become a fundamental claim by kinds of evaluation subjects. However, the satisfaction is the citizen's subjective measurement which may be easily affected by their subjective understanding and preference, so lots of scholars doubt its accuracy. Generally, the samples shall be enough and representative to ensure the reliability of satisfaction. The simple random sampling shall be 
abandoned and stratified random sampling be adopted to select the respondents, by which the accuracy and validity of evaluation can be ensured scientifically and reasonably from the source of performance information.

\section{Conclusion}

As the government performance evaluation involves various kinds of participators, whether they share the common views on relevant issues will directly affect their attitude and behaviors during the evaluation, so the reliability and validity of evaluation results will also be influenced. The participators will actively attend the evaluation activities with an objective and fair attitude until they fully understand and accept the government performance evaluation. The three kinds of respondents involved in the interview are the typical representatives of different interest bodies. Their different cognitive differences on government performance evaluation reflect that there is still a gap between opinions held of different interested parties on the evaluation practice and our theoretical supposition. It is of top priority to further enhance the public participation, expand the disclosure range of evaluation results and stipulate relevant laws and regulations for the government performance evaluation in the future.

\section{Acknowledgement}

This research was financially supported by the Social Science Foundation (ID: 12CGL082) from the China National Planning Office of Philosophy and Social Science.

\section{References}

[1] X. Ni, Information Technology, Internal Process and Organizational Performance: An Empirical Research Based on a City Government in China, Journal of Sun Yat-Sen University(Social Science Edition), 2008(3):134-141.

[2] B. Wang, The inherent logic of theory of government performance evaluation, Gansu Social Sciences, 2008(1):199-202.

[3] J. Chen, The New Development of the Study on the Chinese Government Performance Evaluation: Research Background, Knowledge Evolution and Future Questions Journal of Social Sciences. 2011(5):40-47.

[4] Y. Guan, Research on citizen participation in local government performance evaluation, Social Science Front, 2011(6):171-175.

[5] Z. Zhou, Citizen Participation in Government Performance Measurement: A Historical Review and Assessment, Chinese Public Administration, 2008(1):111-118.

[6] S. Xu, "Third Party Assessment" Model in Government Performance Management and its Improvement, Chinese Public Administration, 2011(1):28-32.

[7] Y. Zhuo, Under the view of harmonious society of citizen satisfaction evaluation research, Administrative Tribune, 2011(2):5-8. 